\title{
Plasma Acetone Metabolism in the Fasting Human
}

\author{
G. A. Reichard, JR., A. C. Haff, C. L. Skutches, P. Paul, C. P. Holroyde, and \\ O. E. OwEN, Department of Research, Lankenau Hospital, Philadelphia, \\ Pennsylvania 19151, Department of Medicine and the General Clinical Research \\ Center, Temple University Health Sciences Center, Philadelphia, Pennsylvania \\ 19140
}

A B S T RACT The metabolism of acetone was studied in lean and obese humans during starvation ketosis. Acetone concentrations in plasma, urine, and breath; and rates of endogenous production, elimination in breath and urine, and in vivo metabolism were determined. There was a direct relationship between plasma acetone turnover $\left(20-77 \mu \mathrm{mol} / \mathrm{m}^{2}\right.$ per min) and concentration $(0.19-1.68 \mathrm{mM})$. Breath and urinary excretion of acetone accounted for a $2-30 \%$ of the endogenous production rate, and in vivo metabolism accounted for the remainder. Plasma acetone oxidation accounted for $\cong 60 \%$ of the production rate in 3-d fasted subjects and about $25 \%$ of the production rate in $21-\mathrm{d}$ fasted subjects. About $1-2 \%$ of the total $\mathrm{CO}_{2}$ production was derived from plasma acetone oxidation and was not related to the plasma concentration or production rate. Radioactivity from $\left[{ }^{14} \mathrm{C}\right]$ acetone was not detected in plasma free fatty acids, acetoacetate, $\beta$-hydroxybutyrate, or other anionic compounds, but was present in plasma glucose, lipids, and proteins. If glucose synthesis from acetone is possible in humans, this process could account for $11 \%$ of the glucose production rate and $59 \%$ of the acetone production rate in 21-d fasted subjects. During maximum acetonemia, acetone production from acetoacetate could account for $37 \%$ of the anticipated acetoacetate production, which implies that a significant fraction of the latter compound does not undergo immediate terminal oxidation.

\section{INTRODUCTION}

The extent to which acetone quantitatively contributes to starvation-induced and diabetic ketonemia has remained controversial for many years. With recently developed methods for acetone determination in blood, breath, and urine, coupled with isotope tracer tech-

Address reprint requests to Dr. George A. Reichard, Jr., Lankenau Hospital.

Received for publication 11 August 1978 and in revised form 11 December 1.978. niques, we have measured rates of endogenous acetone production, breath, and urinary excretion and conversion to other biological compounds during starvationinduced ketonemia in the human. In addition, studies were also done to determine the relationship among plasma acetone, acetoacetate (AcAc), ${ }^{1}$ and $\beta$-hydroxybutyrate $(\beta-\mathrm{OHB})$ specific activities during the continuous infusion of $\left[3-{ }^{14} \mathrm{C}\right] \mathrm{AcAc}$.

\section{METHODS}

Subjects. Clinical data for the 15 volunteer subjects who participated in these studies are shown in Table I. The subjects were of both sexes and ranged in age from 22 to $52 \mathrm{yr}$. Before admission, the purpose and potential risks of the procedures were discussed with each subject, and informed written consent was obtained. All subjects had normal hemograms, urinalyses, electrocardiograms, chest radiographs, and sequential multiple analyzer (SMA) $12 / 60$ profiles. 2 -h postprandial blood glucose concentrations were also normal. During starvation, daily intake consisted of one multivitamin capsule (Unicap, The Upjohn Co., Kalamazoo, Mich.) and at least $1,500 \mathrm{ml}$ of water.

$\left[2-{ }^{14} \mathrm{C}\right]$ acetone preparation and administration, sample collection, and analyses. $\left[2-{ }^{14} \mathrm{C}\right]$ acetone (Amersham Corp., Arlington Heights, Ill.), with a $26 \mathrm{mCi} / \mathrm{mmol} \mathrm{sp}$ act, was used in all studies. It was dissolved in ice-cold isotonic saline and sterilized by passage through a $0.22-\mu \mathrm{m}$ Swinnex filter unit (Millipore Corp., Bedford, Mass.). This primary $\left[{ }^{14} \mathrm{C}\right]$ acetone solution contained $25 \mu \mathrm{Ci} / \mathrm{ml}$.

On the day of the isotope study, the subject was at rest on a bed in a special room equipped with an efficient ventilation system to exhaust exhaled ${ }^{14} \mathrm{CO}_{2}$ and to maintain a normal room air-gas content. The subject voided before the study, and urine was collected throughout and at the close of the experimental period and stored on ice in a closed container until the appropriate analyses were performed. An antecubital venous catheter was inserted in each arm for administration of the $\left[{ }^{14} \mathrm{C}\right]$ acetone and for collection of blood samples.

Immediately before use, an aliquot of the primary $\left[{ }^{14} \mathrm{C}\right]$ acetone solution was diluted in a glass syringe with ice-cold isotonic saline, a sample was removed for radiochemical assay, and the remaining solution was rapidly administered intra-

${ }^{1}$ Abbreviations used in this paper: AcAc, acetoacetate; $\beta$ $\mathrm{OHB}, \beta$-hydroxybutyrate. 
TABLE I

Clinical Data*

\begin{tabular}{cccc}
\hline & Height & $\begin{array}{c}\text { Weight on day } \\
\text { of study }\end{array}$ & $\begin{array}{c}\text { Body surface } \\
\text { area }\end{array}$ \\
\hline $\begin{array}{c}\text { Nonobese, 3-d } \\
\text { fasted } \\
(n=6)\end{array}$ & $c m$ & $k g$ & $m^{2}$ \\
$\begin{array}{l}\text { Mean } \pm \text { SEM } \\
\text { (range) }\end{array}$ & $179 \pm 5$ & $72.3 \pm 4.6$ & $1.91 \pm 0.09$ \\
$\begin{array}{c}\text { Obese, 3-d } \\
\text { fasted } \\
(n=6)\end{array}$ & $(165-193)$ & $(59.5-87.3)$ & $(1.65-2.12)$ \\
$\begin{array}{c}\text { Mean } \pm \text { SEM } \\
\text { (range) }\end{array}$ & $164 \pm 3$ & $108.7 \pm 7.4$ & $2.11 \pm 0.07$ \\
Obese, 21-d & $(160-177)$ & $(82.7-137.8)$ & $(1.90-2.41)$ \\
$\begin{array}{l}\text { fasted } \\
(n=3)\end{array}$ & & & \\
$\begin{array}{l}\text { Mean } \pm \text { SEM } \\
\text { (range) }\end{array}$ & $168 \pm 8$ & $124.1 \pm 13.9$ & $2.29 \pm 0.18$ \\
\hline
\end{tabular}

* On admission, nonobese subjects were $-7-+16 \%$ and the obese subjects $+38-+155 \%$ of ideal body weight based on Metropolitan Life Insurance Tables, 1959. $n$ is the number of subjects in each group from which the mean was obtained. The range of values in each group is shown in parentheses.

venously. The quantity of $\left[{ }^{14} \mathrm{C}\right]$ acetone administered was 26.6-70.7 $\mu \mathrm{Ci}, 1.01-2.72 \mu \mathrm{mol}$.

Beginning $1 \mathrm{~h}$ after $\left[{ }^{14} \mathrm{C}\right]$ acetone administration, and at hourly intervals thereafter, heparinized blood samples were withdrawn and plasma obtained by centrifugation at $4^{\circ} \mathrm{C}$.

The method to determine plasma acetone concentration and radioactivity was based on the use of plasma to avoid possible time-related spontaneous decarboxylation of AcAc, which could occur during preparation of protein-free filtrates. AcAc, originally present in plasma, was first converted to $\beta-\mathrm{OHB}$, using $\beta$-OHB dehydrogenase, after which acetone was isolated from the reaction mixture by distillation. This method has been published in detail ( 1 ) and will be briefly outlined as follows. The conversion of AcAc to $\beta$-OHB was carried out in a distilling flask connected to an all-glass apparatus to avoid possible loss of acetone during the incubation period. The reaction mixture consisted of plasma (containing not more than $10 \mu \mathrm{mol}$ AcAc), $200 \mu \mathrm{mol}$ phosphate buffer (pH 7.0), 45 $\mu \mathrm{mol}$ NADH, $3 \mathrm{U} \beta$-OHB dehydrogenase, and distilled water to make a final vol of $50 \mathrm{ml}$. After a 2 -h incubation period at room temperature, acetone was removed by distillation (1). $30 \mu \mathrm{mol}$ of carrier AcAc was added to an aliquot of the distillate and treated as previously described to obtain Denigè's salt of acetone for counting (2). Acetone concentration in the distillate was determined by an automated procedure (1) based on the alkaline-salicylaldehyde method of Procos (3). Radioactivity in AcAc was obtained as the difference between plasma samples treated as above and equivalent plasma samples in which the conversion of AcAc to $\beta$-OHB was not done. $\beta$-OHB radioactivity was obtained from the residue remaining after distillation of acetone and AcAc by converting $\beta-O H B$ to AcAc enzymatically and repeating the distillation.

Aqueous, plasma, and whole blood standards containing known amounts of $\left[2-{ }^{14} \mathrm{C}\right]$ acetone, $\left[3-{ }^{14} \mathrm{C}\right] \mathrm{AcAc}$, and $\left[3-{ }^{14} \mathrm{C}\right]-\beta-$ OHB (as the D[-] isomer) were subjected to the complete procedure, and $97-101 \%$ of added radioactivity was routinely recovered in the expected fractions.
Aliquots of pooled urine were assayed for acetone concentration and radioactivity in acetone, AcAc, and $\beta$-OHB by the procedure described for plasma. Appropriate modifications in urine sample size or the reaction mixture components were made to not exceed the capacity of the system for converting AcAc to $\beta$-OHB.

AcAc and $\beta$-OHB concentrations in plasma and urine were determined with enzymatic techniques (4). AcAc concentrations and acetone concentrations and radioactivity in plasma and urine were determined on the day of study.

The determination of acetone concentration in expired air presented special problems because of significant loss of this compound when air collections were made by usual techniques employing Douglas bags. A special device, consisting of a calibrated 2-liter glass suction flask equipped with a $1.5-\mathrm{cm}$ diameter glass inlet tube, was used. The side arm of the suction flask was fitted with a rubber septum through which samples of collected air were removed with Pressure-Lok gas syringes (Supelco, Inc., Bellefonte, Pa.). Breath collections were made by having the subject breathe through the inlet tybe at a normal rate and volume for $3 \mathrm{~min}$, after which the collecting device was closed. Acetone concentration was determined on 100 - to 500 $\mu l$ air samples with a gas chromatograph equipped with a flame ionization detector and a $183 \mathrm{~cm} \times 2-\mathrm{mm}$ glass column packed with Carbopack c/0.1\% SP-1000 (Supelco, Inc.). Acetone concentration was determined from peak height by comparison with gaseous acetone standards prepared in calibrated 2-liter suction flasks. Acetone output in breath was calculated from the breath acetone concentration and the minute-volume, measured with the Douglas bag technique.

Respiratory gas samples were also obtained simultaneously with each blood sample for analysis of $\mathrm{O}_{2}, \mathrm{CO}_{2}$, and ${ }^{14} \mathrm{CO}_{2}$ content (5). Preliminary studies with prepared air samples containing $\left[{ }^{14} \mathrm{C}\right]$ acetone showed no contamination of the $\mathrm{CO}_{2}$ trap of the Fredrickson and Ono system (6) which is used in our laboratory to determine $\mathrm{CO}_{2}$ specific activity.

Incorporation of radioactivity into plasma glucose and anionic compounds, including lactate, was estimated with methods previously described (7). Briefly, this procedure consisted of the preparation of a protein-free filtrate of plasma (8), the elimination of $\left[{ }^{14} \mathrm{C}\right]$ acetone from the filtrate by partial evaporation with heat under a stream of nitrogen, and separation of neutral from charged molecules with an Amberlite MB-3 (Rohm and Haas Co., Philadelphia, Pa.) resin column. Glucose in the column eluate was oxidized to gluconic acid with glucose oxidase and isolated for counting purposes with a second column of Amberlite CG-400 resin. Anionic compounds were eluted from the MB-3 column for counting with $0.5 \mathrm{M} \mathrm{NaCl}$.

Total radioactivity in plasma and urine was determined with Bray's solution (9), in plasma free fatty acids by a previously described method (5), in plasma total lipids after extraction by the method of Folch et al. (10), and in plasma proteins after precipitation with $6 \%$ perchloric acid. The protein precipitate was washed twice with $6 \%$ perchloric acid, extracted by the method of Folch et al. (10), and the delipidated protein was suspended and counted in Scintisol (Isolab, Inc., Akron, Ohio).

Calculations. After $\left[{ }^{14} \mathrm{C}\right]$ acetone administration, the linear decline in plasma acetone specific activity with time, which was observed in all subjects, is compatible with first-order reaction-rate kinetics. During each study period, the plasma acetone concentration remained constant, indicating steadystate conditions were present. From the known quantity and specific activity of injected $\left[{ }^{14} \mathrm{C}\right]$ acetone and the extrapolated zero time plasma acetone specific activity, the acetone pool was calculated. The fractional replacement rate of acetone $(k)$ was obtained with the simplified equation $k=0.693 / t_{1 / 2}$, where $t_{1 / 2}$ was determined from the slope of the specific activity curve. 
The acetone turnover rate was calculated as the product of the acetone pool and fractional replacement rate. The apparent acetone space was calculated from the acetone pool and the average plasma acetone concentration with the assumption that this concentration was uniformly present throughout the entire space.

Studies with $\left[3-{ }^{14} \mathrm{C}\right] A c A c$. Two nonobese subjects received a primed continuous infusion of $\left[3-{ }^{14} \mathrm{C}\right] \mathrm{AcAc}$ for $6 \mathrm{~h}$ instead of single injections of $\left[{ }^{14} \mathrm{C}\right]$ acetone. The methods for preparation and administration of the $\left[{ }^{14} \mathrm{C}\right] \mathrm{AcAc}$ have been published (2). During the infusion period, hourly blood samples were obtained, and plasma acetone, AcAc, and $\beta-O H B$ concentrations and specific activities were determined as described.

\section{RESULTS}

Venous plasma ketone-body concentrations. Table II shows the mean venous plasma ketone-body concentrations in each group of subjects during the isotopetracer study periods. After a 3-d fast, plasma acetone, AcAc, and $\beta$-OHB concentrations in the nonobese subjects were significantly greater than in the obese subjects. Plasma ketone-body concentrations in 21-d fasted obese subjects were also significantly greater than in 3-d fasted obese subjects. In some subjects, plasma acetone concentrations were close to or greater than plasma AcAc concentrations. Plasma AcAc and $\beta-\mathrm{OHB}$ concentrations were similar to those previously reported for subjects of similar body weights and duration of fast (11).

Specific activity of plasma acetone, glucose, and

TABLE II

Venous Plasma Ketone-Body Concentrations*

\begin{tabular}{cccc}
\hline & Acetone & AcAc & $\beta$-OHB \\
\hline $\begin{array}{c}\text { Nonobese, 3-d } \\
\text { fasted } \\
(n=6)\end{array}$ & & $m M$ & \\
$\begin{array}{c}\text { Mean } \pm \text { SEM } \\
\text { (range) }\end{array}$ & $0.76 \pm 0.16$ & $1.20 \pm 0.07$ & $3.57 \pm 0.37$ \\
Obese, 3-d & $(0.46-1.44)$ & $(0.97-1.51)$ & $(2.80-5.05)$ \\
$\quad$ fasted & & & \\
$\quad(n=6)$ & & & \\
$\begin{array}{c}\text { Mean } \pm \text { SEM } \\
\text { (range) }\end{array}$ & $0.29 \pm 0.04 \ddagger$ & $0.70 \pm 0.08 \ddagger$ & $2.16 \pm 0.51 \S$ \\
Obese, 21-d \\
fasted \\
$\quad(n=3)$
\end{tabular}

* Mean \pm SEM values shown are of individual mean values obtained during each study period. The range of individual means is in parentheses. $n$ is the number of subjects in each group.

$\ddagger P \leq 0.01$ vs. noniobese, 3 -d fasted and obese, 21 -d fasted. $\S P \leq 0.05$ vs. nonobese, 3-d fasted and obese, $21-\mathrm{d}$ fasted.

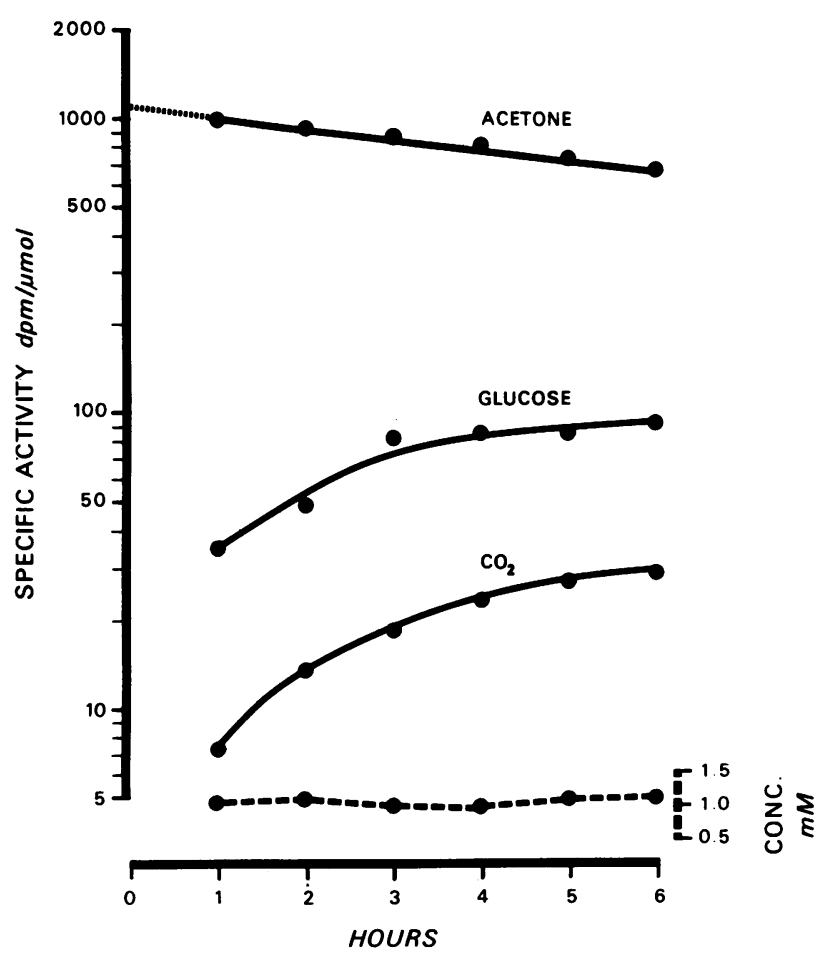

Figure 1 Time-course changes in the specific activity of plasma acetone, glucose, and breath $\mathrm{CO}_{2}$. The steady-state plasma acetone concentration is shown at the bottom of the figure. The obese subject had fasted for $21 \mathrm{~d}$. Conc., concentration.

breath $\mathrm{CO}_{2}$. Fig, 1 shows the time-course changes in the specific activities of plasma acetone, glucose, and breath $\mathrm{CO}_{2}$ after the pulse administration of $\left[{ }^{14} \mathrm{C}\right]-$ acetone to a 21-d fasted obese subject. During the 6-h study period, the plasma acetone concentration was constant while the specific activity slowly declined at a linear rate. The specific activities of plasma glucose and breath $\mathrm{CO}_{2}$ rose during the study period, but at a gradually decreasing rate. No detectable radioactivity was found in plasma AcAc, $\beta$-OHB, free fatty acids, or anionic compounds in this or any subject of these studies.

Acetone pools, spaces, and fractional replacement rates. Acetone pools ranged from 5.91 to 56.4 $\mathrm{mmol} / \mathrm{m}^{2}$. As shown in the top panel of Fig. 2, there was a direct linear relationship between plasma acetone concentrations and acetone pools. The apparent acetone space, expressed as precent body weight, averaged $76.3 \%(62.1-93.6 \%)$ in $3-\mathrm{d}$ fasted nonobese subjects, $62.5 \%(45.4-86.9 \%)$ in $3-d$ fasted obese subjects, and $58.9 \%(56.1-61.5 \%)$ in 21-d fasted obese subjects. Although of limited physiological significance, these results suggest that acetone was distributed in a space that exceeded total body water. The hydrophylic and lipophylic nature of acetone may be responsible 


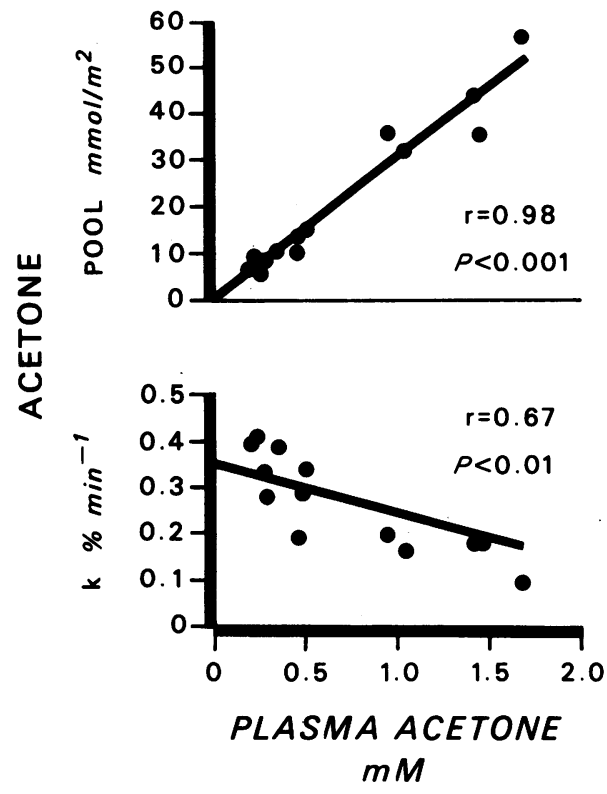

FIGURE 2 Relationship between plasma acetone concentration and acetone pool (top panel) or fractional replacement rate (bottom panel). A significant correlation between concentration and pool $(r=0.98, P<0.001)$ or concentration and fractional replacement rate $(r=0.67, P<0.01)$ was obtained. $\mathrm{K} \% \mathrm{~min}^{-1}$, fractional replacement rate.

for this. The bottom panel of Fig. 2 shows an inverse relationship between the fractional replacement rates of the acetone pool and the plasma acetone concentrations.

Acetone turnover rates. Fig. 3 shows the relationship between the acetone turnover rates, expressed as micromoles per square meter per minute, and the plasma acetone concentrations. Values were normalized to square meters of body surface area because of the wide range of body weights of the subjects. Although not shown, a similar, highly significant correlation $(r=0.84, P<0.001)$ was also obtained when the acetone turnover rate was expressed as micromoles per minute. The mean plasma acetone turnover rate in the 3-d fasted nonobese subjects was 51 (20-69) $\mu \mathrm{mol} / \mathrm{m}^{2}$ per min, in the 3-d fasted obese subjects was $31(20-41) \mu \mathrm{mol} / \mathrm{m}^{2}$ per min, and in the $21-\mathrm{d}$ fasted obese subjects was $61(51-77) \mu \mathrm{mol} / \mathrm{m}^{2}$ per $\mathrm{min}$. The difference between 3- and 21-d fasted obese subjects was statistically significant $(P<0.002)$.

Urine and breath acetone. The relationship between plasma acetone concentrations and urine or breath concentrations are shown in Fig. 4. Chemically determined urine acetone concentrations, shown by closed circles in the left panel of Fig. 4, were obtained from aliquots of pooled urine collected during the 6-h acetone turnover studies, and the plasma acetone concentrations are average values observed in each sub- ject during the same time period. The chemically determined urine acetone concentrations were $\cong 10$-fold greater than plasma concentrations. However, urine acetone specific activities were considerably less than plasma acetone specific activities, indicating that plasma acetone was not the sole source of urine acetone. At least in part, the lower urine acetone specific activity may have been a result of formation of acetone from unlabeled AcAc in urine during the 6-h collection period. To estimate the fraction of urine acetone derived from plasma, the ratio of urine acetone specific activity to plasma acetone specific activity at the midpoint of each study period was determined. On the basis of these calculations, $\cong 8-29 \%$ of urine acetone was derived from plasma. Urine acetone concentration, calculated from these percentages and the chemically determined concentrations, are shown as open circles in the left panel of Fig. 4. Rates of acetone excretion in urine, based on chemically determined and corrected urine acetone concentrations are shown in Table III. For all subjects, plasma acetone clearance ranged from 0.8 to $2.3 \mathrm{ml} / \mathrm{min}$, suggesting marked renal reabsorption or back-diffusion of the compound.

The relationship between breath and plasma acetone concentrations is shown in the right panel of Fig. 4. The range of breath acetone concentrations observed in our subjects is similar to that previously reported in fasting humans (12). Below plasma acetone concentrations of $\cong 0.5 \mathrm{mM}$, ratios of plasma to breath concentrations were in the range of 500:1-600:1, whereas at higher plasma concentrations, the ratios were somewhat smaller, i.e., 350:1-500:1. In the human, after the oral ingestion of acetone, a blood:breath ratio of 330:1 at blood concentrations of $0.5-1.2 \mathrm{mM}$ has been reported $(13,14)$.

Metabolic and excretory fate of acetone. Under

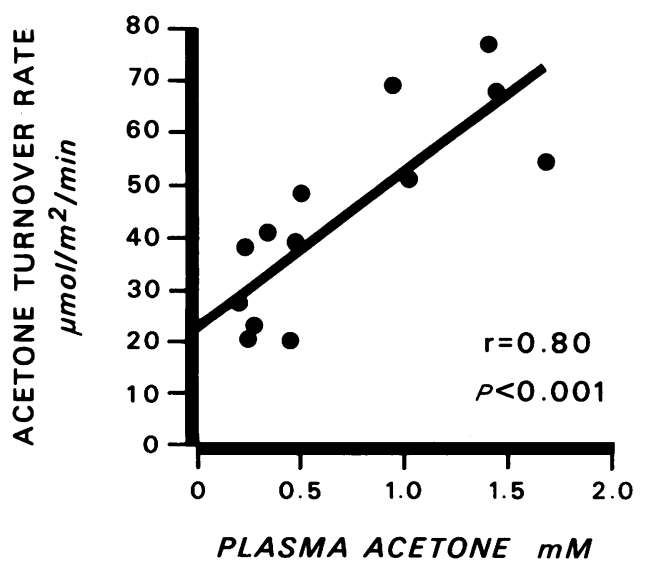

Figure 3 Relationship between plasma acetone concentration and turnover rate. A significant correlation between concentration and turnover rate $(r=0.80, P<0.001)$ was obtained. 


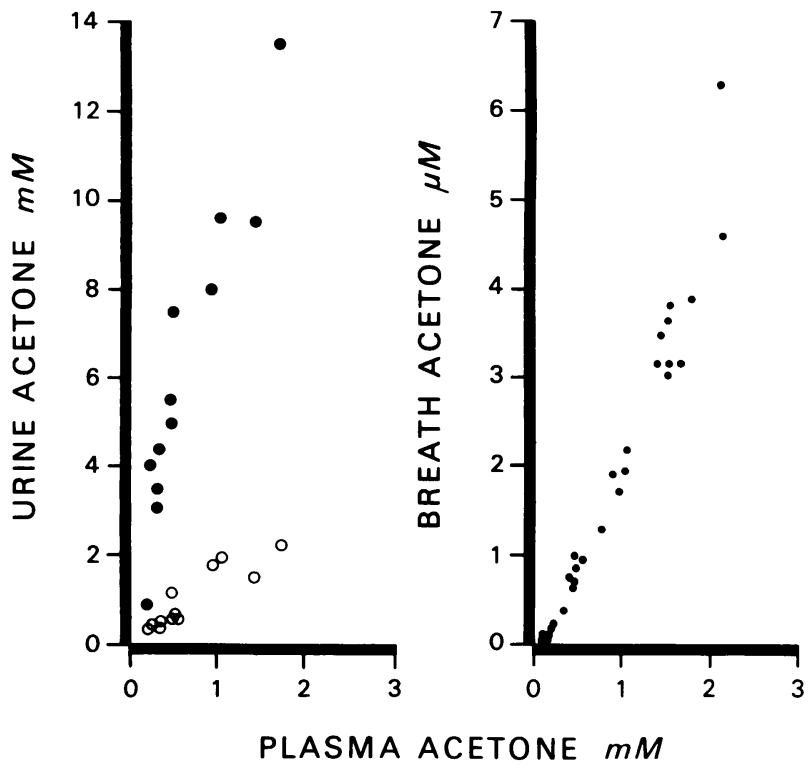

FIGURE 4 Relationship between plasma acetone concentration and urine concentration (left panel) or breath concentration (right panel). Urine concentrations represented by closed circles were chemically determined, and those by open circles were calculated from urine and plasma specific activities (see text).

steady-state conditions, the acetone turnover rate is equal to its rate of production and disappearance. Table IV shows the percent of the measured acetone production rate which could be accounted for by breath and urinary excretion and, by difference, other in vivo metabolic fates in each subject. In general, the fraction of the acetone production rate accounted for by breath and urinary excretion was directly related to the acetone production rate and plasma concentration. Conversely, the fraction of the acetone production rate accounted for by in vivo metabolism decreased with increasing production rates and plasma concentrations. In all subjects, however, in vivo metabolism was the major mechanism for acetone disposal. ${ }^{2}$ Similar results have also been obtained in studies in rats and humans after administration of large quantities of nonradioactive acetone $(14,15)$.

Incorporation of $\left[{ }^{14} \mathrm{C}\right]$ acetone radioactivity into other compounds. After $\left[{ }^{14} \mathrm{C}\right]$ acetone administration, radioactivity was found in numerous other biological compounds. Cumulative ${ }^{14} \mathrm{CO}_{2}$ excretion during the 6-h turnover study periods in the 3 -d fasted nonobese, obese, and 21-d fasted obese subjects accounted for $17.4 \%(10.7-21.3 \%), 21.5 \%(12.9-28.7 \%)$, and $4.9 \%$ $(3.1-7.1 \%)$, respectively, of the administered $\left[{ }^{14} \mathrm{C}\right]-$ acetone radioactivity. The lowest cumulative ${ }^{14} \mathrm{CO}_{2}$ excretion occurred in the most acetonemic subjects and probably reflects dilution of the administered $\left[{ }^{14} \mathrm{C}\right]$ acetone in larger body acetone pools. In all subjects, the respiratory $\mathrm{CO}_{2}$ specific activity curves were similar to that shown in Fig. 1, i.e., the values observed at $6 \mathrm{~h}$ were probably close to the maximum which would have been achieved if our studies had been prolonged. With the 6-h values of plasma acetone and respiratory $\mathrm{CO}_{2}$ specific activities, the percent $\mathrm{CO}_{2}$ derived from plasma acetone oxidation was calculated from the equation: $\%=\left(\mathrm{sp}\right.$ act $\mathrm{CO}_{2} / \mathrm{sp}$ act acetone $\left.\div 3\right) \times 100$. Values for the 3-d fasted nonobese, obese, and 21-d fasted obese subjects were $1.62 \%(1.25-1.80 \%), 1.51 \%$ $(0.82-2.12 \%)$, and $1.11 \%(0.73-1.33 \%)$, respectively. Total respiratory $\mathrm{CO}_{2}$ outputs in these same groups were 4.58 (3.28-5.69), 4.40 (3.57-5.06), and 4.14 (4.00$4.38) \mathrm{mmol} / \mathrm{m}^{2}$ per min. From the total respiratory $\mathrm{CO}_{2}$ outputs and the percent $\mathrm{CO}_{2}$ derived from acetone oxi-

\footnotetext{
${ }^{2}$ Preliminary studies in our laboratory have shown that acetone excretion through skin can account for no more than $0.5 \%$ of the production rate per square meter of body surface
} area.

TABLE III

Urine Acetone Concentration, Specific Activity Ratio, and Excretion

\begin{tabular}{|c|c|c|c|c|c|}
\hline & $\begin{array}{l}\text { Chemical } \\
\text { concentration }\end{array}$ & $\begin{array}{l}\text { Urinary } \\
\text { excretion }\end{array}$ & $\begin{array}{l}\text { Specific } \\
\text { activity } \\
\text { ratio }\end{array}$ & $\begin{array}{l}\text { Corrected } \\
\text { concentration }\end{array}$ & $\begin{array}{l}\text { Corrected } \\
\text { excretion }\end{array}$ \\
\hline Nonobese, 3-d fasted ( $n=4)$ & $\mu \mathrm{mol} / \mathrm{ml}$ & $\mu \mathrm{mol} / \mathrm{min}$ & $\%$ & $\mu \mathrm{mol} / \mathrm{ml}$ & $\mu \mathrm{mol} / \mathrm{min}$ \\
\hline $\begin{array}{l}\text { Mean } \pm \text { SEM } \\
\text { (range) }\end{array}$ & $\begin{array}{c}7.6 \pm 0.8 \\
(5.5-9.5)\end{array}$ & $\begin{array}{c}6.4 \pm 1.2 \\
(4.2-9.2)\end{array}$ & $\begin{array}{l}17 \pm 3 \\
(8-23)\end{array}$ & $\begin{array}{c}1.2 \pm 0.3 \\
(0.6-1.8)\end{array}$ & $\begin{array}{c}1.2 \pm 0.4 \\
(0.4-2.1)\end{array}$ \\
\hline Obese, 3-d fasted $(n=6)$ & & & & & \\
\hline $\begin{array}{l}\text { Mean } \pm \text { SEM } \\
\text { (range) }\end{array}$ & $\begin{array}{c}3.5 \pm 0.6 \\
(1.9-4.9)\end{array}$ & $\begin{array}{c}3.1 \pm 0.5 \\
(1.5-5.1)\end{array}$ & $\begin{array}{l}14 \pm 3 \\
(8-29)\end{array}$ & $\begin{array}{c}0.4 \pm 0.04 \\
(0.3-0.6)\end{array}$ & $\begin{array}{l}0.4 \pm 0.06 \\
(0.2-0.6)\end{array}$ \\
\hline Obese, $21-\mathrm{d}$ fasted $(n=3)$ & & & & & \\
\hline $\begin{array}{l}\text { Mean } \pm \text { SEM } \\
\text { (range) }\end{array}$ & $\begin{array}{l}14.6 \pm 3.2 \\
(9.6-20.6)\end{array}$ & $\begin{array}{c}8.1 \pm 1.5 \\
(5.1-9.7)\end{array}$ & $\begin{array}{c}18 \pm 1 \\
(16-20)\end{array}$ & $\begin{array}{c}2.6 \pm 0.6 \\
(1.9-3.7)\end{array}$ & $\begin{array}{c}1.7 \pm 0.1 \\
(1.5-1.9)\end{array}$ \\
\hline
\end{tabular}

$n$ is the number of subjects in each group from which the mean was obtained. The range values in each group is shown in parentheses. 
TABLE IV

Acetone Disposal Mechanisms

\begin{tabular}{cccc}
\hline & \multicolumn{2}{c}{ Percentage of acetone turnover rate accounted for as } \\
\cline { 2 - 4 } & $\begin{array}{c}\text { Breath } \\
\text { excretion }\end{array}$ & $\begin{array}{c}\text { Urinary } \\
\text { excretion }\end{array}$ & $\begin{array}{c}\text { Other } \\
\text { metabolic } \\
\text { fates }\end{array}$ \\
\hline & $\%$ & $\%$ & $\%$ \\
$\begin{array}{c}\text { Nonobese, 3-d } \\
\text { fasted } \\
(n=4)\end{array}$ & & & \\
$\begin{array}{c}\text { Mean } \pm \text { SEM } \\
\text { (range) }\end{array}$ & $14.7 \pm 2.3$ & $1.4 \pm 0.5$ & $83.9 \pm 2.6$ \\
$\begin{array}{c}\text { Obese, 3-d } \\
\text { fasted } \\
(n=6)\end{array}$ & $(10.3-19.2)$ & $(0.4-2.7)$ & $(79.1-89.3)$ \\
$\begin{array}{c}\text { Mean } \pm \text { SEM } \\
\text { (range) }\end{array}$ & $5.3 \pm 1.8$ & $0.6 \pm 0.1$ & $94.1 \pm 1.8$ \\
$\begin{array}{c}\text { Obese, 21-d } \\
\text { fasted } \\
(n=3)\end{array}$ & $(1.8-12.1)$ & $(0.3-0.8)$ & $(87.1-97.8)$ \\
$\begin{array}{c}\text { Mean } \pm \text { SEM } \\
\text { (range) }\end{array}$ & $25.2 \pm 3.6$ & $1.3 \pm 0.2$ & $73.5 \pm 3.4$ \\
\hline & $(18.1-28.9)$ & $(1.0-1.7)$ & $(70.0-80.2)$ \\
\hline
\end{tabular}

$n$ is the number of subjects in each group from which the mean was obtained. The range of values in each group is shown in parentheses.

dation, plasma acetone oxidation rates of 26 (14-34), $23(10-35)$, and $16(10-19) \mu \mathrm{mol} / \mathrm{m}^{2}$ per $\min$ were obtained. These values must be regarded as only rough approximations because steady-state values of plasma acetone and respiratory $\mathrm{CO}_{2}$ specific activities were not obtained in these single-injection studies. Nevertheless, the results suggest that oxidation of plasma acetone contributed only a small fraction of the total $\mathrm{CO}_{2}$ output and that the rate of oxidation remained fairly constant during the fasting period in spite of changing plasma acetone concentrations, pool sizes, and turnover rates.

Incorporation of radioactivity into plasma glucose was determined in three subjects from each of the three groups studied. In each subject, the time-course changes in plasma glucose specific activity was similar to that shown in Fig. 1, i.e., maximum or near-maximum plasma glucose specific activity was achieved by the 6th $\mathrm{h}$ after $\left[{ }^{14} \mathrm{C}\right]$ acetone administration. With the 6-h values of glucose and acetone specific activities the percent of glucose derived from acetone was calculated from the equation: $\%=([$ sp act glucose $\div 6] /[$ sp act acetone $\div 3]) \times 100$. The average values for the 3 - $d$ fasted nonobese, obese, and 21-d fasted obese subjects were $4.2 \%(2.6-5.8 \%), 3.1 \%(2.8-3.4 \%)$, and $11.0 \%(8.5-$ $13.5 \%$ ), respectively. These results must also be regarded as only rough approximations because steadystate plasma acetone and glucose specific activities were not achieved in these studies.
In two obese, 3-d fasted subjects, preliminary studies were done to determine time-course incorporation of radioactivity from $\left[{ }^{14} \mathrm{C}\right]$ acetone into plasma lipids and perchloric-acid precipitable protein. After $\left[{ }^{14} \mathrm{C}\right]$ acetone administration, radioactivity in both fractions increased in a linear manner. After $1 \mathrm{~h}$, plasma lipids contained $1-2 \%$ of plasma total radioactivity and, by the 6 th $h$, these values had increased to $2-5 \%$. Radioactivity in plasma proteins was $3-4 \%$ of plasma total radioactivity after $1 \mathrm{~h}$ and increased to $20-30 \%$ after $6 \mathrm{~h}$.

Plasma ketone-body specific activities during $\left[3-{ }^{14} \mathrm{C}\right]-$ AcAc infusion. To define the relationship among the specific activities of the three plasma ketone bodies and to determine the immediate precursor of plasma acetone, two nonobese subjects were fasted for $3 \mathrm{~d}$ and administered $\left[3-{ }^{14} \mathrm{C}\right] \mathrm{AcAc}$ by primed-continuous infusion (2). Fig. 5 shows time-course changes in plasma acetone, AcAc, and $\beta$-OHB specific activities in one of the subjects, the same pattern being also observed in the other subject. The specific activities of AcAc and $\beta$-OHB were constant but, unlike previous similar studies $(2,16-18)$, were also equal to each other during the entire experimental period. The specific activity of acetone was at first less than that of the other ketone bodies but, by the 2 nd $h$, the values became equal. This lag period was probably a result of mixing of $\left[{ }^{14} \mathrm{C}\right]$ acetone derived from the administered $\left[{ }^{14} \mathrm{C}\right] \mathrm{AcAc}$ with the existing acetone pool. These results suggest that plasma AcAc is the immediate precursor of plasma acetone, and that the lack of isotopic equilibration between AcAc and $\beta$-OHB previously noted by numerous investigators employing $\left[3-{ }^{14} \mathrm{C}\right] \mathrm{AcAc}$ as the tracer $(2$, 16-18) was probably a result of contamination of AcAc radioactivity by the presence of acetone. However, lack of isotope equilibrium between AcAc and $\beta-O H B$, which has also been reported during infusion of labeled $\beta$-OHB (17), cannot be explained on the basis of these observations.

\section{DISCUSSION}

Changes in the concentrations and rates of production and use of plasma AcAc and $\beta$-OHB during starvation-

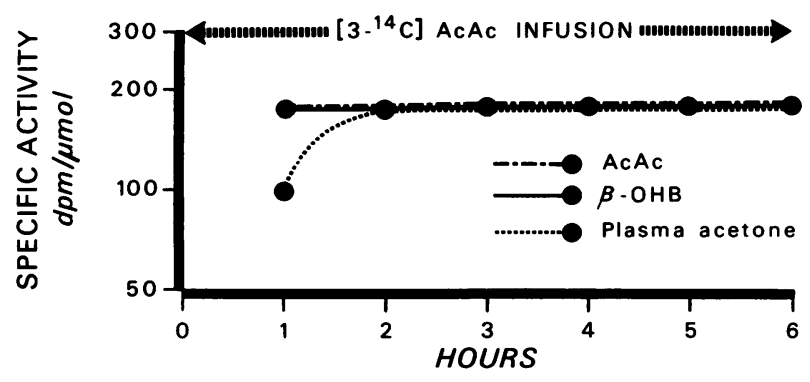

Figure 5 Time-course changes in plasma acetone, AcAc, and $\beta$-OHB specific activities during the primed-continuous infusion of $\left[3-{ }^{14} \mathrm{C}\right] \mathrm{AcAc}$. 
induced ketosis in the human have been described (11), but similar data for the remaining ketone-body, acetone, have not been reported. The presence of acetone in breath (19-23) and biological fluids (22-24) during ketosis has been documented in the literature. However, lack of satisfactory methods to quantitatively determined acetone, and the suspicion that the presence of the compound was solely a result of spontaneous generation from AcAc, precluded an active research interest in its biological and physiological importance.

Our data show that acetone was present in plasma, urine, and breath of the fasting human in whom appreciable concentrations and rates of endogenous production and use were observed. The concentration of plasma acetone in some subjects was equal to or greater than that of plasma AcAc and also in the range of values recently reported in ketotic diabetic patients (22).

There was a direct relationship between plasma acetone concentrations and rates of endogenous production with highest concentrations and production rates occurring in two 3-d fasted nonobese subjects and in obese subjects fasted for $21 \mathrm{~d}$. In the latter subjects, the average rate of plasma acetone production was 137 $\mu \mathrm{mol} / \mathrm{min}$. During fasting, maximum AcAc production rates of about $370 \mu \mathrm{mol} / \mathrm{min}$ have been reported (11). Thus, conversion of AcAc to acetone could account for $\cong(137 / 370) \times 100=37 \%$ of the AcAc produced in the fasting human, implying that a significant fraction of AcAc production may not undergo immediate terminal oxidation.

Depending upon the plasma acetone concentration, excretion of the compound in breath and urine could account for $\cong 2-30 \%$ of the endogenous acetone production rate (Table IV). Conversion of acetone to other biological compounds is, therefore, an important disposal mechanism. This is in agreement with previous studies in rats and humans given acetone orally $(14,15)$. In our subjects, cumulative ${ }^{14} \mathrm{CO}_{2}$ excretion could account for $\cong 5-20 \%$ of the administered $\left[{ }^{14} \mathrm{C}\right]$ acetone, which suggests that oxidation may play an important role in acetone elimination. Similar conclusions from animal experiments have been reported by others (2528). Approximated rates of acetone oxidation represented $\cong 50-70 \%$ of the production rates in nonobese and obese 3 - $d$ fasted subjects and $\cong 25 \%$ of the production rates in $21-\mathrm{d}$ fasted obese subjects. Whether acetone is oxidized directly or after conversion to other compounds, such as glucose, cannot be determined from our studies.

The appearance of radioactivity in plasma glucose, lipids, and proteins supports the results of somewhat similar studies in animals in which labeled carbon of acetone was found in cholesterol (25), liver glycogen $(26,28)$, and various amino acids derived from liver and carcass protein $(26,28)$. Incorporation of radioactiv- ity from acetone into glucose suggests the possibility of gluconeogenesis from the compound, or a metabolite(s) of the compound, a process for which evidence has been obtained in rats $(28)$ and ketotic cows $(29,30)$. On the basis of our specific activity data, we have calculated that $\cong 4-11 \%$ of plasma glucose production could theoretically be derived from acetone. The value of $11 \%$ was obtained in 21-d fasted obese subjects in whom net splanchnic and renal glucose release rates of $\cong 370 \mu \mathrm{mol} / \mathrm{min}$ might be anticipated (31). Thus, the rate of glucose production from acetone would be $(11 / 100) \times 370=40 \mu \mathrm{mol} / \mathrm{min}$, requiring $80 \mu \mathrm{mol} / \mathrm{min}$ glucose equivalents of acetone or $59 \%$ of the plasma acetone production rates measured in these subjects. It is recognized that these calculations are based on an unproven assumption that net glucose synthesis from acetone can occur in the human. They were done, however, to gain some insight into the possible importance of this pathway as a mechanism for acetone disposal.

With isotope-tracer techniques, production rates of ketone bodies have been measured in animals $(16,17)$ and in the human $(2,18)$. In many of these studies employing $\left[3-{ }^{14} \mathrm{C}\right] \mathrm{AcAc}$ as the tracer, the calculation of turnover rates was complicated by the lack of isotopic equilibration between AcAc and $\beta-O H B$. Failure to obtain equilibrium was unexpected and difficult to understand. The results of our preliminary studies employing $\left[3-{ }^{14} \mathrm{C}\right] \mathrm{AcAc}$ infusions suggest that the disequilibrium may have been a result of the presence of unsuspected or incompletely removed $\left[{ }^{14} \mathrm{C}\right]$ acetone in the AcAc fraction. In these studies, total ketone-body production rates, calculated with the mean specific activity of acetone, AcAc, and $\beta-\mathrm{OHB}$, were $\cong 10-15 \%$ greater than the values obtained with the mean total ketone-body specific activity as previously reported (2). Additional studies are required to confirm these observations.

\section{ACKNOWLEDGMENTS}

The authors gratefully acknowledge the technical assistance of Maureen Donohue, Sharon Jarman, Joseph Ottaviano, and the nursing staff of the Clinical Research Unit.

This work was supported by National Institutes of Health Research grants AM-13527 and AM-16102; General Clinical Research Centers Branch grant 5 M01 RR 349; and Biomedical Research Support grant 5-S07-RR-05585-11.

\section{REFERENCES}

1. Haff, A. C., and G. A. Reichard, Jr. 1977. A method for estimation of acetone radioactivity and concentration in blood and urine. Biochem. Med. 18: 308-314.

2. Reichard, G. A., Jr., O. E. Owen, A. C. Haff, P. Paul, and W. M. Bortz. 1974. Ketone body production and oxidation in fasting obese humans. J. Clin. Invest. 53: 508-515.

3. Procos, J. 1961. Modification of the spectrophotometric determination of ketone bodies. Clin. Chem. 7: 97-106. 
4. Williamson, D. H., J. Mellanby, and H. A. Krebs. 1962. Enzymatic determination of $D(-)$ - $\beta$-hydroxybutyric acid and acetoacetic acid in blood. Biochem. J. 82: 90-106.

5. Issekutz, B., Jr., P. Paul, H. I. Miller, and W. Bortz. 1968. Oxidation of plasma FFA in lean and obese humans. Metab. Clin. Exp. 17: 62-73.

6. Fredrickson, D. S., and K. Ono. 1958. An improved technique for assay of ${ }^{14} \mathrm{CO}_{2}$ in expired air using the liquid scintillation counter. J. Lab. Clin. Med. 51: 147-151.

7. Holroyde, C. P., T. G. Gabuzday, R. C. Putnam, P. Paul, and G. A. Reichard. 1975. Altered glucose metabolism in metastatic carcinoma. Cancer Res. 35: 3710-3714.

8. Somogyi, M. 1945. Determination of blood sugar. J. Biol. Chem. 160: 69-73.

9. Bray, G. A. 1960. A simple efficient liquid scintillator for counting aqueous solutions in a liquid scintillation counter. Anal. Biochem. 1: 279-285.

10. Folch, J., M. Lees, and G. H. Sloane Stanley. 1956. A simple method for the isolation and purification of total lipids from animal tissue. J. Biol. Chem. 226: 497-509.

11. Owen, O. E., and G. A. Reichard, Jr. 1975. Ketone body metabolism in normal, obese and diabetic subjects. Isr. J. Med. Sci. II: 560-570.

12. Göschke, H., and Th. Lauffenburger. 1975. Aceton in der atemluft und ketone im venenblut bei vollständigem fasten normal und übergewichtigu personen. Res. Exp. Med. 165: 233-244.

13. Widmark, E. M. P. 1920. Studies in the acetone concentration in blood, urine and alveolar air. The elimination of acetone through the lungs. Biochem. J. 14: 379-394.

14. Haggard, H. W., L. A. Greenberg, and J. M. Turner. 1944. The physiological principles governing the action of acetone together with determination of toxicity. J. Ind. Hyg. Toxicol. 26: 133-151.

15. Koehler, A. E., E. Windsor, and E. Hill. 1941. Acetone and acetoacetic acid studies in man. J. Biol. Chem. 140: 811825.

16. Bates, M. W., H. A. Krebs, and D. H. Williamson. 1968. Turnover rates of ketone bodies in normal, starved and alloxan diabetic rats. Biochem. J. 110: 655-661.

17. McGarry, J. D., M. J. Guest, and D. W. Foster. 1970. Ketone body metabolism in the ketosis of starvation and alloxan diabetes. J. Biol. Chem. 245: 4382-4390.
18. Balasse, E. O., and M. A. Neef. 1975. Inhibition of ketogenesis by ketone bodies in fasting humans. Metab. Clin. Exp. 24: 999-1007.

19. Hubbard, R. S. 1920. Determination of acetone in expired air. J. Biol. Chem. 43: 57-65.

20. Briggs, A. P., and P. A. Shaffer. 1921. The excretion of acetone from the lungs. J. Biol. Chem. 48: 413-428.

21. Levey, S., O. J. Balchum, V. Medrano, and R. Jung. 1964. Studies of metabolic products in expired air. II. Acetone. J. Lab. Clin. Med. 63: 574-584.

22. Sulway, M. J., and J. M. Malins. 1970. Acetone in diabetic ketoacidosis. Lancet. I: 736-740.

23. Crofford, O. B., R. E. Mallard, R. E. Winton, N. J. Rogers, J. C. Jackson, and U. Keller. 1977. Acetone in breath and blood. Trans. Am. Clin. Climatol. Assoc. 88: 128-139.

24. Peden, V. H. 1964. Determination of individual serum ketone bodies with normal values in infants and children. J. Lab. Clin. Med. 63: 332-343.

25. Price, T. D., and D. Rittenberg. 1950. The metabolism of acetone. I. Gross aspects of catabolism and excretion. $J$. Biol. Chem. 185: 449-459.

26. Mourkides, G. A., D. C. Hobbs, and R. E. Koeppe. 1959. The metabolism of acetone-2-C $\mathrm{C}^{14}$ by intact rats. J. Biol. Chem. 234: 27-30.

27. Bergman, E. N., A. F. Sellers, and F. A. Spurrell. 1960. Metabolism of $\mathrm{C}^{14}$-labeled acetone, acetate and palmitate in fasted pregnant and nonpregnant guinea pigs. Am. J. Physiol. 198: 1087-1093.

28. Sakami, W., and H. Rudney. 1952. The metabolism of acetone and acetoacetate in the mammalian organism. Brookhaven Symp. Biol. 5: 176-191.

29. Luick, J. R., A. L. Black, M. G. Simesen, M. Kametaka, and D. S. Kronfeld. 1967. Acetone metabolism in normal and ketotic cows. J. Dairy Sci. 50: 544-549.

30. Black, A. L., J. R. Luick, S. L. Lee, and K. Knox. 1972. Glucogenic pathway for acetone metabolism in the lactating cow. Am. J. Physiol. 222: 1575-1580.

31. Owen, O. E., M. S. Patel, B. S. B. Block, T. H. Kreulen, G. A. Reichard, and M. A. Mozzoli. 1976. Gluconeogenesis in normal, cirrhotic and diabetic humans. In Gluconeogenesis: Regulation in Mammalian Species. R. W. Hanson and M. A. Mehlman, editors. John Wiley \& Sons, Inc., New York. 533-558. 